\title{
Molecular Detection of some Antimicrobial Resistance Genes in Salmonella Species Isolated from Commercial Layers in Egypt
}

\author{
Mohammed A. Lebdah ${ }^{1}$, Waffa M. Mohammed ${ }^{2}$, Samah Eid ${ }^{2}$ and Rehab I. Hamed ${ }^{3}$ \\ ${ }^{1}$ Avian and Rabbit Medicine Department, Faculty of Veterinary Medicine, Zagazig University, \\ 44511, Egypt \\ ${ }^{2}$ Reference Laboratory for quality control on poultry production (RLQP). Animal Health \\ Research Institute, Dokki Lab., Giza, Egypt \\ ${ }^{3}$ Reference Laboratory for quality control on poultry production (RLQP). Animal Health \\ Research Institute, Sharkia Branch, Egypt
}

Article History: Received: 7/1/2017 Received in revised form: 25/2/2017 Accepted: 2/3/2017

\begin{abstract}
The present study was done to investigate the wide spread resistance to some antimicrobial groups among Salmonellae isolated from replacement and layer flocks in Egypt. A total of 24 salmonellae were isolated from 200 birds (apparently healthy or diseased suffered from diarrhea, dehydration, respiratory distress and decrease of egg production) and serotyped into $S$. Enteritidis, $S$. Typhimurium, $S$. Kentucky and $S$. Newport. Twenty-one $S$ almonella isolates were examined for resistance genes against different antimicrobials. The resistance pattern of all Salmonella isolates was done using antibiogram, the resistant isolates were examined for the presence of resistance coding genes using PCR technique. The investigated resistance genes were (qnrS, aac $\left(6^{\prime}\right)$-ib-cr) for quinolone resistant isolates, blaTEM for $\beta$-lactam resistant isolates, $\operatorname{aad} \mathrm{A} 1$ and $\operatorname{aad} \mathrm{A} 2$ for aminoglycosides resistant isolates and $\operatorname{tet} \mathrm{A}(\mathrm{A})$ and $\operatorname{tet} \mathrm{A}(\mathrm{B})$ for tetracycline resistant isolates. Resistant genes percentages for $\operatorname{tet} \mathrm{A}(\mathrm{A}), \operatorname{tet} \mathrm{A}(\mathrm{B}), \operatorname{blaTEM}, \operatorname{aad} \mathrm{A} 1$, aadA2, aac (6')-ib-cr and $q n r S$ in the examined isolates were 70\%, 20\%, 93.3\%, 30\%, 80\%, $10 \%$ and $15 \%$, respectively. In conclusion, at the study area, antimicrobial resistance genes are widely spread in Salmonella isolates. Thus, minimizing the influence of antibiotics in treatment and prevention.
\end{abstract}

Keywords: Salmonella, Resistance Genes, Replacement Layer, Layers, Egypt

\section{Introduction}

Paratyphoid infection is a problem of economic concern to all phases of poultry industry from production to marketing. Salmonella spp. is gram negative, motile rods by peritrichous flagella. The genus Salmonella is divided into two species Salmonella enterica and $S$. bongori, Salmonella enterica itself is comprised of six subspecies, namely $S$. enterica subspecies enteric, $S$. enterica subspecies salamae, S. enterica subspecies Arizonae, $S$. enterica subspecies diarizonae, $S$. enterica subspecies indica and S.enterica subspecies houtenae [1]. The number of serotypes in each species and subspecies of Salmonella was reported to be around 2522 [25]. As a result of extensive use of antibiotics in human and veterinary medicine, serious increase in the spreading of multiple antibiotic resistant Salmonella has occurred [6]. Prolonged use, misusing, and overusing antibiotics led to in efficiency and enhanced the severity of the disease [7,8]. These resistant Salmonellae can be transmitted to humans through food such as poultry meat, therefore, they constitute a major public health problem [9]. Thus, this study was planned to detect antibiotic resistance genes in Salmonella infected replacement and layer flocks to select the highly effective antimicrobial agents for treatment and prevention.

\section{Material and Methods}

\section{Samples collection}

A total of 200 (apparently healthy (60), diseased (75), freshly dead (65) replacement and layers were collected from Sharkia Governorate and subjected to postmortem examination. The internal organs (liver, caecum, ovary, heart and lungs) were 
aseptically collected and subjected to bacterial isolation and identification.

\section{Bacteriological examination}

Isolation of Salmonella spp. was done according to ISO 6579 [10]. Briefly, samples were collected in buffered peptone water and incubated at $37^{\circ} \mathrm{C}$ for $24 \mathrm{~h}$, after preenrichment $0.1 \mathrm{~mL}$ of the broth culture was transferred into a $10 \mathrm{~mL}$ Rappaport Vassiliadis Soya (RVS) broth and incubated at $42^{\circ} \mathrm{C}$ for 24-48 h. Another $1 \mathrm{~mL}$ of pre-enrichment broth was transferred into a tube containing 10 $\mathrm{mL}$ of Muller Kauffman Tetrathionate Novobiocin (MKTTN) broth and incubated at $37^{\circ} \mathrm{C}$ for $24-48 \mathrm{~h}$. A loop-full of material from the RVS broth and MKTTn was transferred and streaked separately onto the surface of Xylose Lysine Deoxycholate agar (XLD agar), Hektoen Enteric (HE agar), MacConkey's agar and S-S agar separately. Presumptive colonies were selected and purified on nutrient agar plates for further identification.

\section{Biochemical identification}

Identification of the isolates using oxidase reaction, hydrolysis of urea, $\mathrm{H}_{2} \mathrm{~S}$ production, Lysine decarboxylation, Indole test, Methyle red (MR) test, Voges Proskauer (VP) test and Simmon's Citrate agar were done according to Cruickshank et al. [11].

\section{Serotyping}

Biochemically suspected Salmonella isolates were subjected to serological identification according to Kauffman-White Scheme (Kauffman, 1974) for determination of somatic $(\mathrm{O})$ and flagellar $(\mathrm{H})$ antigens [10]. The antisera were kindly supplied by Prof. Dr. Mohamed Ahmed, Faculty of Veterinary Medicine, Benha University, Department of Food Control.

\section{Antibiogram}

The antimicrobial susceptibility testing was performed according to Finegold et al. [12] using the agar disc diffusion method on Mueller Hinton agar (Oxoid) plates. Few colonies of Salmonella were suspended in Muller broth and incubated for 4-5 hours until the turbidity was seen. Using sterile Pasteur pipette, $1 \mathrm{~mL}$ of the suspension was inoculated into the surface of the plate to wet the whole of its surface. Excessive fluid was discarded by its pipetting then plates were dried for up to 30 min then the chosen antibiotic discs were distributed to the surface of the plate.

The used antimicrobial agents were Florfenicol $(30 \mu \mathrm{g})$, Nalidixic acid $(30 \mu \mathrm{g})$, Ciprofloxacin $(5 \mu \mathrm{g})$, Norfloxacin $(10 \mu \mathrm{g})$, Amoxicillin $(10 \mu \mathrm{g})$, Cefotaxime $(30 \mu \mathrm{g})$, Amikacin $(30 \mu \mathrm{g})$, Gentamycin $(10 \mu \mathrm{g})$ Erthromycine $(15 \mu \mathrm{g})$, Streptomycin $(10 \mu \mathrm{g})$, Doxycyclin $(30 \mu \mathrm{g})$ and SulfamethaxezoleTrimethoprim $(25 \mu \mathrm{g})$. The inhibition zone was measured to assess resistance or susceptibility according to the interpretation criteria established by Clinical Laboratory Standards Institute (CLSI) standard [13].

\section{Molecular detection of resistance genes}

The DNA extraction was done using QIAamp DNA Mini Kit DNA extraction kit (Catalogue no. 51304) according to manufactures' guidelines. The Oligonucleotide primers synthesized by Metabion (Germany) targeting several antibiotic resistance genes were used. Primers specific for tetracycline resistance gene tet $\mathrm{A}(\mathrm{A})$ and $\operatorname{tet} \mathrm{A}(\mathrm{B})$ are $\mathrm{F}\left(5^{\prime}-\right.$ GGT TCA CTC GAA CGA CGT CA-3'); R (5'-CTG TCC GAC AAG TTG CAT GA-3') and F (CCT CAG CTT CTC AAC GCG TG'3); R (5'-GCA CCT TGC TCA TGA CTC TT-'3), respectively [14]. Aminoglycosides resistance genes (aadA1 and $\operatorname{aad\mathrm {A}2}$ ) were detected using primers $F\left(5^{\prime}\right.$-TAT CAG AGG TAG TTG GCG TCAT-3'); R (5'- GTT CCA TAG CGT TAA GGT TTC ATT -'3) and F (5'-TGT TGG TTA CTG TGG CCG TA-3') R (5'-GAT CTC GCC TTT CAC AAA GC -3'), respectively $[14,15]$. $\beta$-lactams resistance gene (blaTEM) was detected using primers $\mathrm{F}\left(5^{\prime}\right.$ ATC AGC AAT AAA CCA GC -3') R (5'CCC CGA AGA ACG TTT TC -3') [16]. Quinolones resistance genes $\left(a a c\left(6^{\prime}\right)-i b-c r\right.$ and $q n r S)$ were detected using primers $\mathrm{F}\left(5^{\prime}-\mathrm{CCC}\right.$ GCT TTC TCG TAG CA-3'), R (5'-TTA GGC ATC ACT GCG TCT TC-3') and F(5'-ACG ACA TTC GTC AAC TGC AA -3'), R (5'TAA ATT GGC ACC CTG TAG GC-3'), respectively [17]. Reaction volume of $30 \mu \mathrm{L}$ contained $12.5 \mu \mathrm{L}$ of EmeraldAmp Max PCR Master Mix (Takara, Japan), $1 \mu \mathrm{L}$ of each primer of 20 pmol concentrations, $4.5 \mu \mathrm{L}$ of nucleus free water and $6 \mu \mathrm{L}$ of template DNA. Amplified DNA was separated by electrophoresis on $1.5 \%$ agarose gel (ABgene) 
in $1 \mathrm{x}$ TBE buffer at room temperature. For gel analysis, $15 \mu \mathrm{l}$ of the products was loaded in each gel slot. A 100 bp DNA Ladder (Qiagen, USA) was used to determine the fragment sizes. The gel was photographed by a gel documentation system and the data was analyzed through computer software. The positive control was kindly provided by the Reference Laboratory for the Control of Poultry Production, Dokki, Giza.

\section{Results}

\section{Cultural and biochemical characters}

The cultural characters of the isolated salmonellae appeared on XLD agar are smooth pink colonies with black center $\left(\mathrm{H}_{2} \mathrm{~S}\right.$ production) while, $\mathrm{H}-\mathrm{E}$ agar they appeared as deep blue colored colonies. On MacConkey's agar, the colonies were pale, colorless smooth, transparent (non lactose fermenter) and on S-S agar they appeared as pale colored colonies with or without black centers.

Application of different biochemical tests revealed the following results; negative oxidase reaction, negative urea hydrolysis, positive reaction on TSI agar, positive reaction on LI agar, negative Indole reaction, positive MR reaction, negative VP reaction and positive on Simmon's Citrate agar.

Table 1: Isolation percentages of Salmonellae in organs of infected layer chickens

\begin{tabular}{lcc}
\hline Samples & Positive Number & Percent \\
\hline Liver & 9 & $37.5 \%$ \\
Caecum & 8 & $33.3 \%$ \\
Ovary & 5 & $20.8 \%$ \\
Heart & 2 & $8.3 \%$ \\
Lungs & 0 & $0 \%$ \\
\hline
\end{tabular}

\section{Occurrence of Salmonella spp. in different samples}

Out of 200 examined birds, 24 (12\%) were positive for Salmonella isolation. The isolation percentages from liver, caecum, ovaries, heart and lungs were $37.5 \%, 33.3 \%, 20.8 \%$ and $8.3 \%$, respectively, while none of the lung samples were positive (Table1).

\section{Serotyping of Salmonella isolates}

The isolated 24 salmonellae were classified under four different serogroups including $S$. Enteritidis, $S$. Typhimurum, $S$. Kentucky and $S$. New port. The most prevalent serogroups were $S$. Enteritidis and $S$. Typhimurium with the percentage of $54.2 \%$ and $20.8 \%$, respectively. Other serotypes including $S$. Kentucky and $S$. Newport were also recorded with the percentages of $8.3 \%$ and $4.2 \%$, respectively. While, 3 isolates $(12.5 \%)$ were untypeable

\section{Antimicrobial susceptibility}

The results in Table 2 show that Salmonella isolates revealed high resistance to nalidixic acid (95.2\%) and Amoxycillin (71.4\%). Moderate resistance to erythromycin $(47.6 \%)$, streptomycin $(47,6 \%)$, doxycycline $(52.4 \%)$, gentamycin (47.6\%), florophenicol $(52.4 \%)$ and sulfamethaxezole/ trimethoprim (38.1\%) was observed. Moreover, the isolates were sensitive to amikacin $(80,9 \%)$; ciprofloxacin (76.2\%), norofloxacine $(71.2 \%)$ and cefotaxime $(52.4 \%)$. Table (3) shows that multiple drug resistance to more than two antimicrobial drugs was observed in all the examined isolates. 
Table 2: Antibiogram of different Salmonellae isolates

\begin{tabular}{lccc}
\hline \multirow{2}{*}{ Antibiotic } & & Percentage of samples (n) & \\
\cline { 2 - 4 } & Sensitive & Intermediate & Resistant \\
\hline Nalidixic acid & & & $95.2 \%(20)$ \\
Amikacine & 0 & $19.1 \%(1)$ & 0 \\
Ciprofloxacin & $80.9 \%(17)$ & $23.8 \%(5)$ & 0 \\
Norofloxacin & $76.2 \%(16)$ & $28.6 \%(6)$ & 0 \\
Cefotaxime & $71.4 \%(15)$ & $33,3 \%(7)$ & $14.3 \%(3)$ \\
Doxycycline & $52.4 \%(11)$ & $14,28 \%(3)$ & $47.6 \%(10)$ \\
Sulfamethoxazol / & $38.1 \%(8)$ & $38.1 \%(8)$ & $28.6 \%(6)$ \\
trimethoprim & $33.3 \%(7)$ & $28,58 \%(6)$ & $47.6 \%(10)$ \\
Streptomycine & & $57.14 \%(12)$ & $23.8 \%(5)$ \\
Florophenicol & $23.8 \%(5)$ & $33.33 \%(7)$ & $47.6 \%(10)$ \\
Gentamycin & $19.1 \%(4)$ & $38,1 \%(8)$ & $47.6 \%(10)$ \\
Erthromycine & $19.1 \%(4)$ & $19.05 \%(4)$ & $71.4 \%(15)$ \\
Amoxycillin & $14.3 \%(3)$ & & \\
\hline The & $9.3 \%(2)$ & & \\
\hline
\end{tabular}

The remained 3 isolates out of 24 obtained isolates were untypable.

Table 3: Antibiotic resistance pattern of Salmonella serotypes

\begin{tabular}{|c|c|c|c|}
\hline Isolate No & Serotype & Resistance profile & \\
\hline 1 & $S$. Enteritidis & NA-AML-DO-E & \\
\hline 2 & $S$. Typhimurium & NA-AML-SXT & \\
\hline 3 & S. Kentucky & NA-AML-S-E- DO & \\
\hline 4 & $S$. Newport & NA-CN-E-SXT & \\
\hline 5 & $S$. Enteritidis & NA-CN-S-E-SXT & \\
\hline 6 & $S$. Enteritidis & NA-AML-DO-F & \\
\hline 7 & S. Typhimurium & NA-AML-CN- & \\
\hline 8 & S. Kentucky & NA-AML-CN-S-SXT & \\
\hline 9 & $S$. Enteritidis & NA-CN-DO-S-F & \\
\hline 10 & $S$. Enteritidis & NA-DO-E-F-SXT & \\
\hline 11 & S. Typhimurium & CN-S-E-SXT & \\
\hline 12 & $S$. Enteritidis & NA-AML-CN-S & \\
\hline 13 & $S$. Enteritidis & NA-AML-DO-SXT & \\
\hline 14 & S. Typhimurium & NA-DO-S-E & \\
\hline 15 & S. Typhimurium & NA-AML-S-E-CTX & \\
\hline 16 & $S$. Enteritidis & NA-AML-CN-DO & \\
\hline 17 & $S$. Enteritidis & NA-AML-E-F-CTX & \\
\hline 18 & $S$. Enteritidis & NA-AML-DO-S-E & \\
\hline 19 & $S$. Enteritidis & NA-AML-CN-DO & \\
\hline 20 & $S$. Enteritidis & NA-AML-CN & \\
\hline 21 & $S$. Enteritidis & NA-AML-S--F-CTX & \\
\hline $\begin{array}{l}\text { NA=Nalidixic acid } \\
\text { DO=Doxycyclin }\end{array}$ & $\begin{array}{ll}\text { AK=Amikacine } & \mathbf{C I P}=\text { Ciprofloxacine } \\
\mathbf{S}=\text { Streptomycine } & \mathbf{E}=\text { Erthromycine }\end{array}$ & $\begin{array}{cc}\text { NOR=Norfloxacin } & \text { AML }=\text { Amoxycillin } \\
\text { F }=\text { Florophenicol } & \text { CTX }=\text { Cefotaxime }\end{array}$ & $\mathbf{C N}=$ Gentamycin \\
\hline
\end{tabular}

\section{Molecular detection of resistance associated genes}

Salmonella isolates that showed phenotypic resistance against different antimicrobial agents using antibiotic susceptibility test were examined by PCR to identify some resistance coding genes. The results revealed that $\operatorname{tet} \mathrm{A}(\mathrm{A}), \operatorname{tet} \mathrm{A}(\mathrm{B}), \operatorname{blaTEM}, \operatorname{aad} \mathrm{A} 1, \operatorname{aad} \mathrm{A} 2, \operatorname{aac}$ (6')-ib-cr and $q n r S$ were identified in $70 \%$, $20 \%, 93.3 \%, 30 \%, 80 \%, 10 \%$ and $15 \%$, respectively (Table 4).

\section{Discussion}

In this study, 200 replacement and layers from different poultry farms at Sharkia Governorate were examined for the presence of Salmonella species. Twenty-four (12\%) of the 
examined birds were found positive. This was in agreement with Rehan [18] and Mohamed [19] who isolated Salmonella species from Dakahlia and Damietta Governorates in Egypt with an isolation rates of $12 \%$ and $12.4 \%$, respectively. Meanwhile, these results were higher than $9.2 \%$ and $3.4 \%$ reported by AL-
Abadi and Al-Mayah [20] and AL-Hakeem [21], respectively. These differences in the overall prevalence of Salmonella may be related to several factors such as environment, hygienic conditions of the farm and health status of the examined chicken.

Table 4: Occurrence of resistance genes among examined bacterial strains isolated from layer chickens

\begin{tabular}{|c|c|c|}
\hline Resistance gene & Number of examined resistant isolates & Number of positive (\%) \\
\hline qnrS & 20 & $3(15 \%)$ \\
\hline$a c c(6)-i b-c r$ & 20 & $2(10 \%)$ \\
\hline blaTEM & 15 & $14(93.33)$ \\
\hline $\operatorname{tet} \mathbf{A}(\mathbf{A})$ & 10 & $7(70 \%)$ \\
\hline $\operatorname{tet} \mathbf{A}(\mathbf{B})$ & 10 & $2(20 \%)$ \\
\hline $\operatorname{aad} \mathrm{A} 1$ & 10 & $3(30 \%)$ \\
\hline $\operatorname{aad} \mathrm{A} 2$ & 10 & $8(80 \%)$ \\
\hline
\end{tabular}

The prevalence of the isolated bacteria from different internal organs of the examined layers in this study showed that the highest percentage of Salmonella was recorded in liver $(37.5 \%)$ followed by cecum $(33,3 \%)$, ovary $(20.8 \%)$ and heart $(8.3 \%)$. These results are in agreement with Dhahar et al. [22] and AL-Iedani [23]. ALAbadi and Al-Mayah [20] recorded that the highest percentage of Salmonella isolation was from cecum which is the primary sites of colonization of Salmonella due to the anatomical and structural location that allows the cecum to act as a blind sac with low content flow rate.

Salmonella strains which are resistant to a range of antimicrobials have emerged and are threatening to become a serious public health problem [8]. This resistance results from the misuse of antimicrobials both in human and poultry husbandry. In this study, 21 typable Salmonella isolates from replacement and layers were examined against 12 different antimicrobial agents belonged to different groups such as quinolone, phenicol, $\beta$-lactams, aminoglycosides, tetracyclines, cephlosporins and sulfonamide groups. Antibiogram of Salmonella isolates showed high resistance to nalidixic acid $(95.2 \%)$ and amoxicillin $(71.4 \%)$. The obtained results differ from Habrun et al. [24] who reported that $100 \%$ Salmonella isolates were sensitive to florophenicol and streptomycin, while, 92 of the isolates $(58 \%)$ were sensitive to nalidixic acid. In addition, Okamoto et al. [25] reported that florophenicol is the most effective antimicrobial for treating Salmonella infection as a result of lack of use of this antimicrobial in animals feed since 2003. In contrary to the obtained results, Cardoso et al. [26] reported that $100 \%$ of Salmonella isolates showed sensitivity to doxycycline, while, Shivhare et al. [27] reported high sensitivity of Salmonella spp. isolated from poultry to norfloxacin, while, all the isolates were resistant to sulfonamides trimethoprim. Moreover, our results agreed with Snow et al. [28] who reported that all Salmonella isolates from commercial layer flocks in UK were sensitive to amikacin. The results in this study differ from Zdragas et al. [29] who reported 5\% resistance to streptomycin and $2 \%$ to nalidixic acid. Khan et al. [30] reported that $87.9 \%$ of salmonellae were sensitive to ciprofloxacin and amikacin. Moreover, Donado-Godoy et al. [31] reported that the resistance pattern of Salmonella isolated from chickens was $15 \%$ to ciprofloxacin, trimethoprim-sulfamethoxazole, streptomycin, and nalidixic acid. On the other hand, $8 \mathrm{~S}$. Enteritidis isolates showed 100\% sensitivity to ciprofloxacin, norfloxacin and gentamycin [26]. Also, Yah and Eghafona [32] reported that 183 Salmonella isolates from 
chickens were highly resistant to chloramphenicol, gentamycin, trimethoprim and sulfamethoxazole and to lesser extent resistant to ciprofloxacin. Our results agreed with Threlfall [33] and Hendriksen [34] who recorded that $S$. Typhimurum isolates were resistant to amoxicillin, chloramphenicol, streptomycin and sulfonamides. In contrary to the obtained results in the current study, Asway et al. [35] mentioned that the isolated Salmonella strains were resistant to ciprofloxacin.
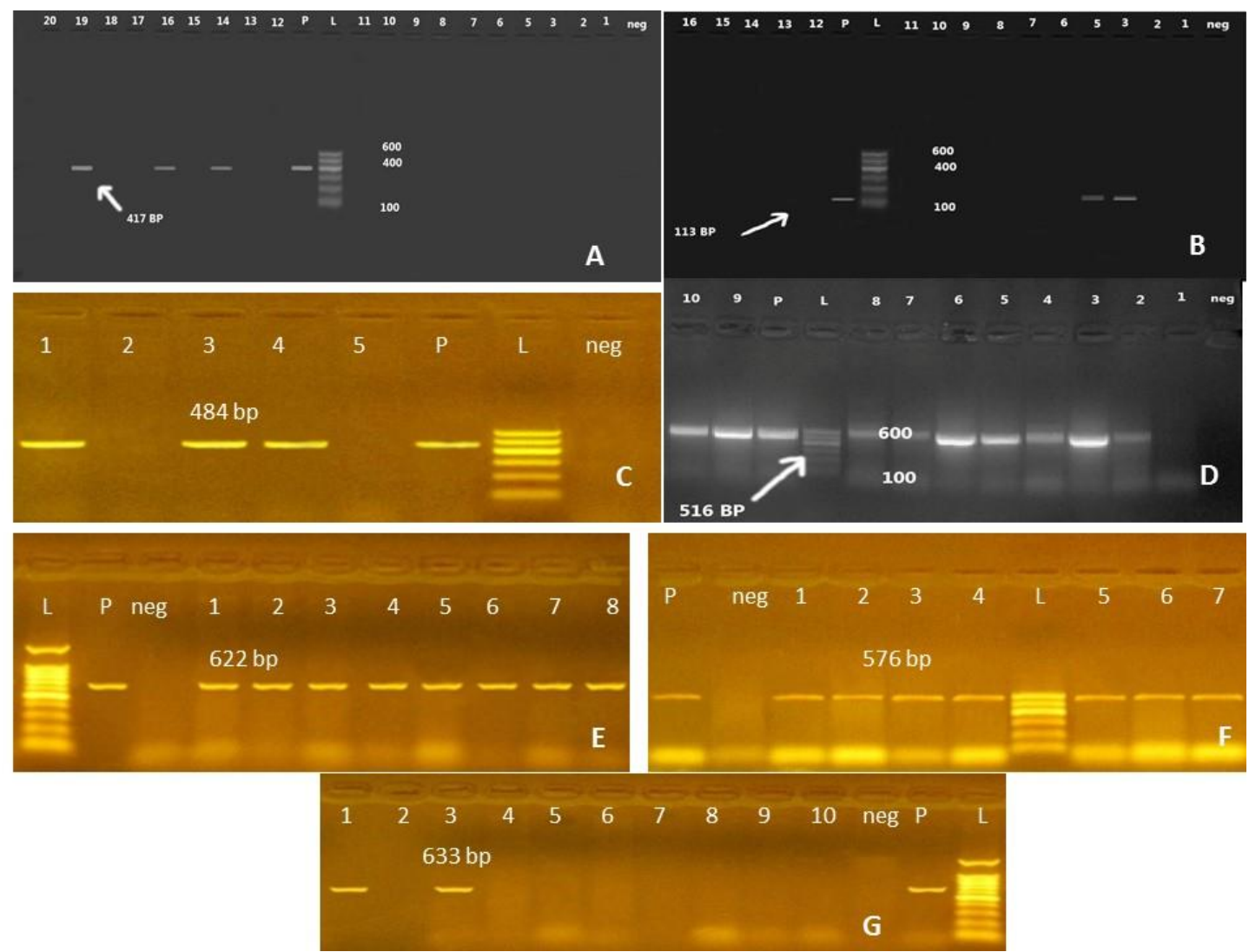

Figure 1: Exemplar of gel pictures showing amplified products of resistance associated genes; In each photo "P" stands for positive control, "neg": Negative control and numbers indicates lanes with positive and negative samples; A: qnrS gene (417bp); B: acc(6)-ib-cr gene (113bp); C: aadA1 gene(484bp); D: blaTEM gene(516 bp); E: aad 22 gene(622bp); F: $\operatorname{tet} \mathrm{A}(\mathrm{A}) \operatorname{gene}(576 \mathrm{bp}) ; \mathrm{G}: \operatorname{tet} \mathrm{A}(\mathrm{B}) \operatorname{gene}(633 \mathrm{bp})$.

All Salmonella isolates from poultry origin were resistant to at more than one antimicrobial, indicating multiple drug resistance. These findings confirm that poultry is a major reservoir of multi-resistant Salmonella and this had no correlation with the presence of antimicrobial resistance gene indicating that other mechanisms of acquiring resistance could be present $[25,36]$. Molecular identification of Salmonella resistance genes showed that $q n r S$ and $a a c\left(6^{\prime}\right)-i b$-cr resistance genes for quinolones were reported with the percentages of $15 \%$ and $10 \%$, respectively. This with inconstant with Kim et al. [37] who investigated the prevalence and characteristics of plasmid mediated quinolone resistance genes ( $\left.q n r, a a c\left(6^{\prime}\right)-i b-c r\right)$ and found that $3.2 \%$ of the isolates contained $q n r$ genes but none carried the aac $\left(6^{\prime}\right)-i b$-cr. While, Hao et al. [38] reported $a a c\left(6^{\prime}\right)-i b-c r$ and $a n r S$ resistance genes in Salmonella isolates with the percentages of $20.2 \%$ and $1.6 \%$, respectively.

The blaTEM gene, a gene encoded for $\beta$ lactamases resistance was reported in the present study with the percentage of $93.3 \%$. This was similar to a study performed by Hur et al. [39] who reported that $90.5 \%$ of penicillin resistant $S$. Enteritidis carried the blaTEM gene. In another study, the percentage of blaTEM was $10 \%$ which was identified in 10 Salmonella isolates from retail chicken meat [40]. However, blaTEM gene was 
detected in 51.6\% resistant Salmonella isolates [41]. Aslam et al. [42] reported that the percentage of blaTEM gene in Salmonella isolated from retail meats in Canada was $17 \%$ and this gene was the most common resistance genes found. A total of 108 $S$. Indiana possessed blaTEM gene with a percentage of $81.2 \%$ [43]. The aadA2 gene, a gene encoded for streptomycin resistance was reported in the present study with the percentage of $80 \%$. These results agree with a study performed by Shahada et al. [44] who reported that all streptomycin resistant $S$. Infantis from poultry in Japan carried aadA1 gene, while, Mohamed [19] recorded that 17 isolates possessed aadA1 gene with the percentage $53.1 \%$. Sheng et al. [45] reported lower percentage of aadA2 gene in only three Salmonella isolates out of seventy-three isolates.

The tetA gene, a gene encoded for tetracycline resistance was reported in the present study with the percentage of $70 \%$. Higher percentage was obtained by Lu et al. [46] who reported that 108 Salmonella isolates possessed tetA gene with the percentage of $81.2 \%$. Moreover, Shahada et al. [44] reported that $89 \%$ of oxytetracyclineresistant Salmonella from poultry carried the tet(A) gene. Percentages ranging from $66.7 \%$ $100 \% \%$ of Salmonella carriage of tetracycline resistance gene tet $\mathrm{A}$ were reported by several studies [39,47-50]. Another study by Aslam et al. [42] reported that the percentage of tet(A) gene in Salmonella isolates was $28 \%$. Bacci et al. [51] recorded that tet class genes are considered the most common types in gram negative bacteria, also tetA and tet $\mathrm{B}$ genes are located inside non-conjugative transposons which are important way for the horizontal transfer of antibiotic resistance.

\section{Conclusion}

It could be concluded that the antimicrobial resistance genes of Salmonella infected chickens were extensively spread in the study area. Thus, leading to minimizing the influence of antibiotics in both treatment and prevention and increase public health significance. Therefore, other tools of prevention and treatment are important to avoid this problem.

\section{Conflict of interest}

The authors declare no conflict of interest.

\section{References}

[1] Selvaraj, R.; Das, D.; Ganguly, S.; Ganguli, M.; Dhanalakshmi, S. and Mukhoadhayay, K. (2010): Characterization and antibiogram of Salmonella spp from poultry specimens. J Microbiol Antimic, 2(9) :123-126.

[2] Brenner, F. W.; Villar, R. G.; Angulo, F. J.; Tauxe , R. and Swaminathan, B. (2000): Salmonella nomenclature. J Clin Microbial, 38(7):2465-2467.

[3] Su, L. and Chiu, C. (2007): Salmonella: clinical importance and evolution of nomenclature. Chang Gung Med J, 30(3):210-219.

[4] Bertrand, S. (2010): Rapport Annuel 2009Centre National de Référece des Salmonella et Shigella-Souches de Salmonella et Shigella isolées en Belgique en 2009.

[5] Oludairo, O.O.; Kwaga, J.K.P.; Dzikwi, A.A. and Kabir, J. (2013): The genus Salmonella, isolation and occurrence in wildlife. Int $\mathrm{J}$ Microbiol Immunol Res, $1(5): 47-52$.

[6] Cruchaga, S.; Echieta, A.; Aladuena, A.; Garcia-Pena, J.; Frias, N. and Usera, M.A. (2001): Antimicrobial resistance in Salmonella from human food and animals in Spain. J. Antimicrob Chemother, 47: 315321.

[7] WHO (2002): World Health organization. Department of communicable diseases surveillance and response. Geneva, Fact sheet N194.

[8] WHO (2005): World Health organization. Drug-resistant Salmonella. Food safety Geneva, Fact sheet N139.

[9] Khallaf, M.; Ameur, N.; Terta, M.; Lakranbi, M.; Senouci, S. and Ennaji, M.M. (2014): Prevalence and antibiotic resistance of Salmonella isolated from chicken meat marketed in Rabat, Morocco. International Journal of Innovation and Applied Studies, 6(4):1123-1128. 
[10] ISO 6579 (2002): Microbiology of food and animal feeding stuffs-horizontal method for detection of Salmonella spp. International standard. ( $4^{\text {th }}$ edition).

[11] Cruickshank, R.; Duguid, J. P.; Marmion, B.P. and Swain, R.H.A. (1975): Medical microbiology. The practice of Medical Microbiology. 12 ${ }^{\text {th }}$ Ed. Vol. II Churchill Living stone, Edinburgh, London and New York., 2: 170-188.

[12] Finegold, S.M. and Martin, E.T. (1982): Diagnostic microbiology. $6^{\text {th }}$ Ed., The C.V. Mosby Company, St. Louis, Toronto, London.

[13] CLSI (2011): Clinical and Laboratory Standards Institute. Performance Standards for Antimicrobial Susceptibility Testing; Twenty-Fifth Informational Supplement (M100-S25).

[14] Randall, L.P.; Cooles, S.W.; Osborn, M.K.; Piddock, L.J.V.; Woodward, M.J. (2004): Antibiotic resistance genes, integrons and multiple antibiotic resistance in thirty- five serotypes of Salmonella enterica isolated from humans and animals in the UK. J Antimicrob Chemother. 53(2);208- 216.

[15] Walker, R.A.; Lindsay, E. and Woodward, M.J. (2001): Variation in clonality and antibiotic- resistance genes among multi- resistant Salmonella enterica serotype Typhimurium phagetype U302 (MR U302) from humans, animals and foods. Microb Drug Resist, 7(1):13- 21.

[16] Colom, K.; Perez, J.; Alonoso, R.; Fernandez- Arangguiz, A.; Larino, E. and Cisterna, R. (2003): Simple and reliable multiplex PCR assay for detection of blaTEM, blaSHV, blaOXA1 genes in Enterobacteriaceae. FEMS Microbiol Lett, 223 (2):147-151.

[17] Lunn, A.D.; fabrega, A.; SanchezCespedes, J. and Vila, J. (2010): Prevalence of mechanisms decreasing quinolone- susceptibility among Salmonella spp. clinical isolates. Int Microbiol, 13(1):15-20.

[18] Rehan, H.M.A. (2004): Application of PCR identification of Salmonella in chickens. M.V.Sc., Thesis, Fac. Vet. Med., Mansoura Uni., Egypt

[19] Mohamed, N.M (2015): Molecular studies on antibiotic drug resistance Salmonella in poultry. $\mathrm{PhD}$ Thesis, Faculty of Veterinary Medicine, Benha University, Egypt.

[20] Al-Abadi, I.K.M. and AL- Mayah, A.A.S. (2012): Isolation and identification of Salmonella spp. from chicken and chicken environment in Basrah province. Afr J Biol Sci, 7 (1): 33-43 .

[21] Al-Hakeem, Z, Kh. Kh. (2003): Contamination of the parent stock environment with Salmonella . M.Sc Thesis. College of Veterinary Medicine. Musol Univerisity.

[22] Dhahar, F.H.; Awni, M.D.H.; Mahmood, N.R. and Jamil, M.M. (2011): isolation and diagnosis of Salmonella in Animal origin food. Iraq Acad Sci J, 3(5):1-19.

[23] AL-Iedani, A.A.; Khudor, M.H. and Oufi, N.M. (2014): Isolation and identification of Salmonella spp. from poultry farms by using different techniques and evaluation of their antimicrobial susceptibilities. Bas J Vet Res, 13(1): 246-259.

[24] Habrun, B.; Simpraga, B.; Kompes, G. and Krstulovic, F. (2012): Antimicrobial resistance and serotyping of Salmonella enterica subsp. enterica isolated from poultry in Croatia. Veterinarski Arhiv, 82(4):371-381.

[25] Okamoto, A.S; Andreatti Filho, R.L; Rocha, T.S.; Menconi, A. and Maritto, A. (2009): Detection and transfer of antimicrobial resistance gene integron in Salmonella Enteritidis derived from avian material. Revista Brasileira de Ciência Avícola, 11(3):195-201.

[26] Cardoso, M.O.; Ribeiro, A.R.; Santos, L.R.; Pilotto, F.; de Moraes, H.S.; Salle, C.P.; Rocha, S.S. and Nascimento, V.P. (2006): Antibiotic resistance of Salmonella Enteritidis isolated from broiler carcasses. Braz J Microbiol, 37(3): 368-371. 
[27] Shivhare, S.; Sharda, R.; Reddy, A.; Sharma, R. and Sharma, V. (2000): Antibiotic sensitivity of Salmonella Typhimurium isolates from domestic poultry. Ind Vet J, 77 (11): 998-999.

[28] Snow, L.C.; Davies, R.H.; Christiansen, K.H.; Carrique-Mas, J.J.; Wales, A.D.; O'Connor, J.L.; Cook, A.J. and Evans, S.J. (2007): Survey of the prevalence of Salmonella species on commercial laying farms in the United Kingdom. Vet Record, 161(14):471-476.

[29] Zdragas, A.; Mazaraki, K.; Vafeas, G.; Giantzi, V.; Papadopoulos, T. and Ekateriniadou, L. (2012): Prevalence, seasonal occurrence and antimicrobial resistance of Salmonella in poultry retail products in Greece. Lett Appl Microbiol, 55(4):308-313.

[30] Khan, M.; Suryanarayan, P.; Ahmed, M.; Vaswani, R. and Faheem, S. (2010): Antimicrobial susceptibility of Salmonella isolates from chicken meat samples in Dubai, United Arab Emirates. International Journal of Food, Nutrition and Public Health, 3(2):149- 159.

[31] Donado-Godoy, P.; Clavijo, V.; León, M.; Tafur, M.A.; Gonzales, S.; Hume, M.; Alali, W.; Walls, I.; Lo Fo Wong, D.M. and Doyle, M.P. (2012): Prevalence of Salmonella on retail broiler chicken meat carcasses in Colombia. J Food Prot,75(6):1134-1138.

[32] Yah, S.C. and Eghafona, N.O. (2007): Plasmids: A vehicle for rapid transfer of antibiotic resistance markers of Salmonella species in animals. J Amer Sci, 3 (4): 86-92.

[33] Threlfall, E.J. (2002): Antimicrobial drug resistance in Salmonella: problems and perspectives in food and water-borne infection. FEMS Microbiol Reviews, 26(2):141-148.

[34] Hendriksen, S.W. (2004): Animal-toHuman transmission of Salmonella typhimurum DT104A Variant. Emer infect Dis J, 10(12):2225-2227.

[35] Asway, A.M.E. and El-latif, M.M.A. (2010): Some bacteriological and serological studies on enteritis in ducks. Assiut Vet Med J, 56(125):239-249.

[36] Álvarez- Fernandez, E.; Alonso-Calleja, C.; García-Fernández, C. and Capita, R. (2012): Prevalence and antimicrobial resistance of Salmonella serotypes isolated from poultry in Spain: comparison between 1993 and 2006. Int $\mathrm{J}$ food Microbiol, 153(3):281-287.

[37] Kim, J.H.; Cho, J.K. and Kim, K.S. (2013): Prevalence and characterization of plasmid- mediated quinolone resistance genes in Salmonella isolated from poultry in Korea isolated from poultry in Korea. Avian Pathol, 42(3):221-229.

[38] Hao, H.; Yang, B.; Shi, J.; Xi, M.; Wang, X.; Cui, Y. and Meng, J. (2011): drug resistance and related genes of chicken borne Salmonella to quinolone and fluoroquinolones. Wei Sheng Wu Xue $\mathrm{Bao}=$ Acta microbiologica Sinica, 51(10):1413-1420.

[39] Hur, J.; Kim, J.H.; Park, J.H.; Lee, Y.J. and Lee, J.H. (2011): Molecular and virulence characteristics of multidrug resistant Salmonella Enteritidis strains isolated from poultry. Vet $\mathrm{J}$, 189(3):306-311.

[40] Ahmed, A.M.; Shimabukuro, H. and Shimamoto, T.(2009): Isolation and molecular characterization of multidrugresistant strains of Escherichia coli and Salmonella from retail chicken meat in Japan. J Food Sci, 74(7):405-410.

[41] Yang, B.; Qu, D.; Shen, J.; Xi, M.; Zhi, S.; Cui, S.; Ji, B. and Meng, J. (2010): Antimicrobial susceptibility and related genes of Salmonella serovars from retail foodin Shaanxi province. Wei Sheng $\mathrm{Wu}$ Xue $\mathrm{Bao}=$ Acta microbiologica Sinica,50(6):788-796.

[42] Aslam, M.; Checkley, S.; Avery, B.; Chalmers, G.; Bohaychuk, V.; Gensler, G.; Reid-Smith, R. and Boerlin, P. (2012): Phenotypic and genetic characterization of antimicrobial resistance in Salmonella isolated from retail meats in Alberta, Canada. Food Microbiol, 32(1):110-117. 
[43] Lu, Y.; Wu, C.M.; Wu, G.J.; Zhao, H.Y.; He, T.; Cao, X.Y.; Dai, L.; Xia, L.N.; Qin, S.S. and Shen, J.Z. (2011): Prevalence of antimicrobial resistance among Salmonella isolates from chicken in China. Foodborne Pathog Dis, 8(1):45-53.

[44] Shahada, F.; Chuma, T.; Tobata, T.; Okamoto, K.; Sueyoshi, M. and Takase, K. (2006): Molecular epidemiology of antimicrobial resistance among Salmonella enterica serovar Infantis from poultry in Kagoshima, Japan. Int $\mathbf{J}$ Antimicrob Agents, 28(4):302-307.

[45] Sheng, C.; Shaohua, Z.; David, G. W.; Carl, M.; Ran L.; Hanchun, Y.; Patrick, F.; McDermott, S. and Jianghong, M. (2004): Characterization of multiple antibiotic resistant Salmonella serovars Isolated from Retail Meats. Appl Environ Microbiol, 70(1);17.

[46] Lu, Y.; Zhao, H.; Liu, Y.; Zhou, X.; Beier, R.C.; Wu, G. and Hou, X. (2014): Characterization of MultidrugResistant Salmonella enterica Serovars Indiana and Enteritidis from Chickens in Eastern China. PLoS One, 9 (5): e96050. antimicrobial resistance in Salmonella isolated from diseased broilers in Egypt. Microbiol Immunol, 56(4):254-261.

[48] Nde, C.W. and Logue, C.M. (2008): Characterization of antimicrobial susceptibility and virulence genes of Salmonella serovars collected at a commercial turkey processing plant. $\mathbf{J}$ Appl Microbiol,104(1):215-223.

[49] Zhang, C.P.; Ning, Y.; Song, L.; Chen, H. and Chen, R. (2011): Investigation of resistance to tetracycline and distribution of tetracycline resistance genes of Salmonella isolates from poultry. China Poult, 33(3):18-21.

[50] Zou, W.; Frye, J. G.; Chang, C.W.; Liu, J.; Cerniglia, C. E. and Nayak, R. (2009): Microarray analysis of antimicrobial resistance genes in Salmonella enterica from preharvest poultry environment. J Appl Microbiol, 107(3):906-914.

[51] Bacci, C.; Boni, E.; Alpigiani, I.; Lanzoni, E.; Bonardi, S. and Brindani, F. (2012): Phenotypic and genotypic features of antibiotic resistance in Salmonella isolated from chicken meat and chiaken and quail carcasses. Int $\mathrm{J}$ Food Microbiol, 160;16-23.

[47] Ahmed, A. M. and Shimamoto, T. (2012): Genetic analysis of multiple

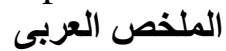

$$
\begin{aligned}
& \text { الكثف الجزيئي على بعض الجينات المقاومة لمضادات الميكروبات فى السالمونيلا المعزولة من الاجاج البياض التجاري }
\end{aligned}
$$

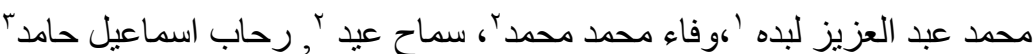

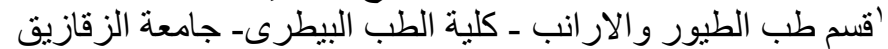

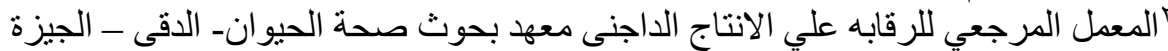

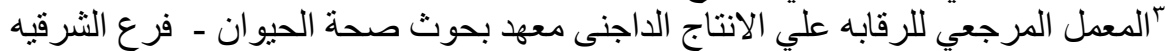

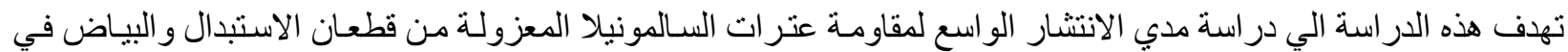

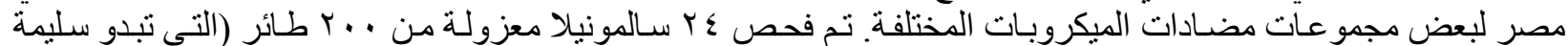

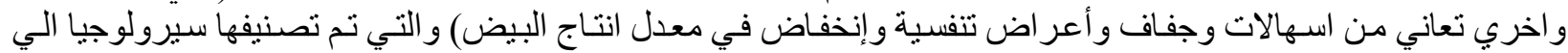
Salmonella Enteritidis, S. Typhimurium, S. Kentucky and S. Newport

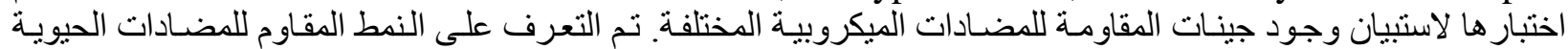

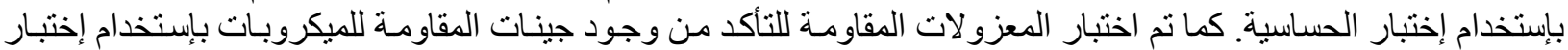

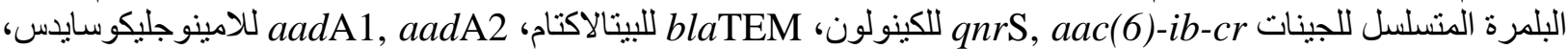

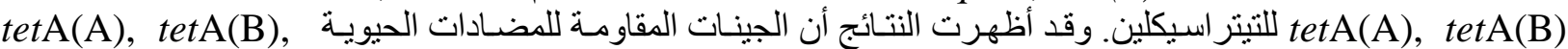
\% ا جائت بالنسب • blaTEM, aadA1, aadA2, aac(6)-ib-cr and qnrS

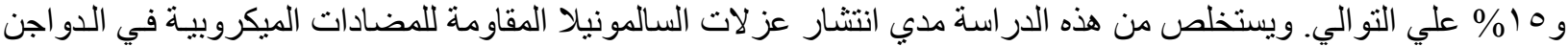

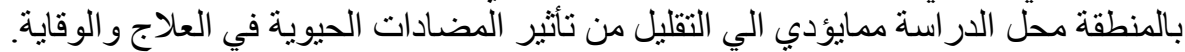

